\title{
Luteolin decreases IGF-II production and downregulates insulin-like growth factor-I receptor signaling in HT-29 human colon cancer cells
}

Do Young Lim ${ }^{1}$, Han Jin Cho ${ }^{1}$, Jongdai Kim ${ }^{2,3}$, Chu Won Nho ${ }^{4}$, Ki Won Lee ${ }^{5}$ and Jung Han Yoon Park ${ }^{1,2^{*}}$

\begin{abstract}
Background: Luteolin is a 3, 4',5,7-tetrahydroxyflavone found in various fruits and vegetables. We have shown previously that luteolin reduces HT-29 cell growth by inducing apoptosis and cell cycle arrest. The objective of this study was to examine whether luteolin downregulates the insulin-like growth factor-I receptor (IGF-IR) signaling pathway in HT-29 cells.
\end{abstract}

Methods: In order to assess the effects of luteolin and/or IGF-I on the IGF-IR signaling pathway, cells were cultured with or without $60 \mu \mathrm{mol} / \mathrm{L}$ luteolin and/or $10 \mathrm{nmol} / \mathrm{L}$ IGF-I. Cell proliferation, DNA synthesis, and IGF-IR mRNA levels were evaluated by a cell viability assay, $\left.{ }^{3} \mathrm{H}\right]$ thymidine incorporation assays, and real-time polymerase chain reaction, respectively. Western blot analyses, immunoprecipitation, and in vitro kinase assays were conducted to evaluate the secretion of IGF-II, the protein expression and activation of IGF-IR, and the association of the p85 subunit of phophatidylinositol-3 kinase (PI3K) with IGF-IR, the phosphorylation of Akt and extracellular signalregulated kinase (ERK)1/2, and cell division cycle 25C (CDC25C), and PI3K activity.

Results: Luteolin (0 - $60 \mu \mathrm{mol} / \mathrm{L})$ dose-dependently reduced the IGF-II secretion of HT-29 cells. IGF-I stimulated HT29 cell growth but did not abrogate luteolin-induced growth inhibition. Luteolin reduced the levels of the IGF-IR precursor protein and IGF-IR transcripts. Luteolin reduced the IGF-I-induced tyrosine phosphorylation of IGF-IR and the association of p85 with IGF-IR. Additionally, luteolin inhibited the activity of PI3K activity as well as the phosphorylation of Akt, ERK1/2, and CDC25c in the presence and absence of IGF-I stimulation.

Conclusions: The present results demonstrate that luteolin downregulates the activation of the PI3K/Akt and ERK1/ 2 pathways via a reduction in IGF-IR signaling in HT-29 cells; this may be one of the mechanisms responsible for the observed luteolin-induced apoptosis and cell cycle arrest.

\section{Background}

Colon cancer is the second most frequent cause of cancer-related death in the Western world [1]. Dietary patterns and lifestyle are the principal determining factors for colorectal cancer risk. The results of epidemiological studies have shown that the consumption of fruits and vegetables can reduce or prevent the risk of colon cancer [2]. Flavonoids are polyphenols, which are

\footnotetext{
* Correspondence: jyoon@hallym.ac.kr

'Department of Food Science and Nutrition, Hallym University, Chuncheon, 200-702, Korea

Full list of author information is available at the end of the article
}

abundantly present in fruits and vegetables, and have been shown to have a variety of biological effects, including cancer prevention.

Insulin-like growth factors (IGFs) are polypeptides that stimulate the growth of a variety of mammalian cells [3]. These effects are mediated through the insulin-like growth factor I receptor (IGF-IR), and IGF-I and IGF-II are well-known ligands of IGF-IR. The binding of these ligands to IGF-IR results in the autophosphorylation of the receptor at the intracellular domain of $\beta$-subunits, resulting in the activation of the intrinsic tyrosine kinase of the IGF-IR. Subsequently, several adaptor molecules
C Biomed Central

(c) 2012 Lim et al; licensee BioMed Central Ltd. This is an Open Access article distributed under the terms of the Creative Commons Attribution License (http://creativecommons.org/licenses/by/2.0), which permits unrestricted use, distribution, and reproduction in any medium, provided the original work is properly cited. 
are recruited and activated via phosphorylation. Two distinct signaling pathways are activated by IGF-IR. The recruitment and activation of growth factor receptorbound protein-2/son of sevenless or Shc can lead to the recruitment and activation of the Ras/Raf/mitogen activated protein kinase (MAPK) cascade, ultimately resulting in the activation of extracellular signal-regulated kinase (ERK)1/2. Alternatively, insulin receptor substrate-1 can be recruited and phosphorylated on multiple tyrosine residues that function as docking sites for the p85 subunit of phosphatidylinositol 3-kinase (PI3K) and activate the PI3K/Akt signaling pathway (reviewed in $[4,5])$. The activation of these pathways induces cell cycle progression and prevents apoptosis [6,7]. IGFs are also strong mitogens and survival factors for a variety of cancer cells, including prostate and colon cancer cells (Reviewed in [8]), and IGF-I and IGF-II mRNA levels were reported to be highly elevated in colon cancer [9]. We have previously reported that, in human colon cancer cells, including HT-29 cells and Caco-2 cells, IGF-II is synthesized and secreted, and an IGF-II autocrine loop stimulates the growth of these cancer cells $[10,11]$.

Luteolin, 3',4',5,7-tetrahydroxyflavone, is found in a variety of vegetables, fruits, and medicinal herbs. Luteolin has been shown to function as an anti-oxidant, antiinflammatory, and anti-cancer agent [12-15]. Additionally, luteolin induces cell cycle arrest and apoptosis in the liver and lung cancer and leukemia cell lines [16-20]. Our previous results indicated that luteolin inhibited HT-29 cell proliferation by inducing cell cycle arrest and apoptosis [21]. Therefore, in this study, we attempted to determine whether luteolin downregulates IGF-IR signaling in HT-29 cells.

\section{Methods}

\section{Cell culture}

Human colon cancer cells (HT-29 and Caco-2 cells) and rat intestinal epithelial cell line-6 (IEC-6 cells) were purchased from the American Type Culture Collection (Manassas, VA) and maintained in DMEM/F12 containing 100 $\mathrm{mL} / \mathrm{L}$ of fetal bovine serum (FBS), with 100,000 U/L of penicillin and $100 \mathrm{mg} / \mathrm{L}$ of streptomycin. In order to determine the effects of luteolin and/or IGF-I on cell growth, we plated the cells with DMEM/F12 containing $10 \%$ FBS. Prior to luteolin treatment, the cell monolayers were subjected to $24 \mathrm{~h}$ of serum starvation with DMEM/ F12 supplemented with $5 \mathrm{mg} / \mathrm{L}$ transferrin, $1 \mathrm{~g} / \mathrm{L} \mathrm{BSA}$, and $5 \mu \mathrm{g} / \mathrm{L}$ selenium (serum-free medium). The cells were then incubated in serum-free medium with or without 60 $\mu \mathrm{mol} / \mathrm{L}$ of luteolin (Sigma, St. Louis, MO, USA) and/or 10 nmol/L IGF-I (R \& D System, Minneapolis, MN, USA) for 24,48 or $72 \mathrm{~h}$. Viable cell numbers were estimated via MTT assays. Luteolin was dissolved in DMSO and all cells were treated with DMSO at a final concentration of $0.1 \%$.

\section{$\left[{ }^{3} \mathrm{H}\right]$ Thymidine incorporation assay}

To determine DNA synthesis, the cells were plated at a density of 6,000 cells per well in 96-well plates and serum-starved as described above. After serum starvation, the cells were incubated for $2 \mathrm{~h}$ in serum-free medium containing 0 or $60 \mu \mathrm{mol} / \mathrm{L}$ of luteolin with or without IGF-I. $0.5 \mu \mathrm{Ci}\left[{ }^{3} \mathrm{H}\right]$ thymidine was then added, and the incubation was continued for another $1 \mathrm{~h}$. The incorporation of $\left[{ }^{3} \mathrm{H}\right]$ thymidine into DNA was estimated as previously described [11].

\section{IGF-II determination}

For the determination of IGF-II, HT-29 cells were plated in $100 \mathrm{~mm}$ dishes at a concentration of $2 \times 10^{6}$ cells/dish and after $24 \mathrm{~h}$, the monolayers were serumstarved and treated with various concentrations of luteolin $(0-60 \mu \mathrm{mol} / \mathrm{L})$ for $24 \mathrm{~h}$. Conditioned media were collected and concentrated 20-fold, and immunoblot analysis was conducted using anti-IGF-II clone S1F2 (Upstate Biotechnology, Inc., Lake Placid, NY, USA) as previously described [22].

\section{Immunoprecipitation and immunoblot analyses}

Cells were incubated for $2 \mathrm{~h}$ with 0 or $60 \mu \mathrm{mol} / \mathrm{L}$ of luteolin, and $10 \mathrm{nmol} / \mathrm{L}$ of IGF-I was added. At 0,1 , or 30 min after the addition of IGF-I, the cell lysates were prepared and immunoprecipitated with indicated antibodies. Immunoblot analyses were conducted as described previously [23]. Signals were detected via the enhanced chemiluminescence method using SuperSignal West Dura Extended Duration Substrate (Pierce, Rockford, IL, USA). The relative abundance of each protein band was analyzed via densitometric scanning of the exposed films. Immunoblots were probed with an antibody for $\beta$-actin as a protein loading control. The following antibodies were purchased from the indicated suppliers: anti-IGF-IR (C-20) (Santa Cruz Biotechnology, Inc., Santa Cruz, CA, USA); anti-phospho-tyrosine-RC20 antibody (PY20) linked to horseradish peroxidase (Transduction Laboratories, Palo Alto, CA, USA); antiPI3K p85 antibody (Upstate Biotechnology, Inc.); antiphospho-IGF-IR (P-IGF-IR, Abcam, Cambridge, MA, USA); and anti-ERK-1/2, anti-P-ERK-1/2 (Thr202/ Tyr203), anti-cell division cycle 25c (CDC25c), anti-PCDC25c, anti-Akt, and anti-P-Akt Ser473 (Cell Signaling Technology, Inc., Beverly, MA, USA).

\section{Real-time-polymerase chain reaction (RT-PCR)}

Total RNA was isolated using RNeasy Plus Mini Kit (Qiagen, Valencia, CA, USA) and cDNA was synthesized using $3 \mu \mathrm{g}$ of total RNA with SuperScript II reverse transcriptase (Invitrogen, Carlsbad, CA, USA). Real time-PCR was conducted as described previously [24]. Sequences used for primer sets were as follows: IGF-IR; 
forward-TGG AGT GCT GTA TGC CTC TG, backward-TGA TGA CCA GTG TTG GCT GG, $\beta$-actin; forward-GTT TGA GAC CTT CAA CAC CCC, backward-GTG GCC ATC TCC TGC TCG AAG TC. The levels of mRNA were normalized to $\beta$-actin and the control $(0 \mu \mathrm{mol} / \mathrm{L}$ luteolin) levels were set to $100 \%$.

\section{$\mathrm{PI} 3 \mathrm{~K}$ assay}

PI3K activity was estimated as described previously [25]. Cell lysates (1 mg protein) were immunoprecipitated with a polyclonal antibody against IGF-IR $\beta$ followed by incubation with protein A-Sepharose beads. After washing, the beads were resuspended in $20 \mu \mathrm{L}$ of kinase buffer containing $4 \mu \mathrm{g}$ of phosphatidylinositol (Sigma, St. Louis, $\mathrm{MO}$, USA), $10 \mu \mathrm{mol} / \mathrm{L}$ of ATP, $5 \mathrm{mmol} / \mathrm{L}$ of $\mathrm{MnCl}_{2}$, and $10 \mu \mathrm{Ci}$ of $\left[\gamma_{-}{ }^{32} \mathrm{P}\right] \mathrm{ATP}$ and incubated for $20 \mathrm{~min}$ at $30^{\circ} \mathrm{C}$. In order to determine whether luteolin directly inhibits the kinase activity of PI3K, active PI3K $\alpha$ (100 ng, Millipore, Billerica, MA, USA) was incubated for $10 \mathrm{~min}$ in the absence or presence of $20 \mu \mathrm{mol} / \mathrm{L}$ of luteolin at $30^{\circ} \mathrm{C}$ in $20 \mu \mathrm{L}$ of kinase buffer. Phosphatidylinositol $(25 \mu \mathrm{g})$ was added and the incubation was continued for another $5 \mathrm{~min}$ at room temperature. $10 \mu \mathrm{Ci}$ of $\left[\gamma-{ }^{32} \mathrm{P}\right] \mathrm{ATP}$ was then added and reactions were incubated for $10 \mathrm{~min}$ at $30^{\circ} \mathrm{C}$. The resultant ${ }^{32} \mathrm{P}$-labeled phosphatidylinositol 3phosphate (PIP) lipids were separated from reaction products by thin layer chromatography (TLC) and visualized by autoradiography. The radioactive PIP signals were quantitated via densitometry using the Bio-profile Bio-1D application (Vilber-Lourmat, France) [23].

\section{Statistical analyses}

Data were expressed as means \pm SEM values and analyzed via analysis of variance. Differences between treatment groups were analyzed by Duncan's multiple range test or Student's t-test. The means were considered significantly different at $P<0.05$. All statistical analyses were conducted using the SAS system for Windows, version 8.12 (SAS, Inc., Cary, NC, USA).

\section{Results}

Luteolin reduces IGF-II secretion in HT-29 cells

In the previous study, we observed that luteolin inhibited HT-29 human colon cancer cell proliferation by inducing cell cycle arrest and apoptosis [21]. However, the treatment of IEC- 6 rat intestinal epithelial cells at the same concentrations $(20-60 \mu \mathrm{mol} / \mathrm{L})$ of luteolin for $24 \mathrm{~h}$ did not alter the viability of these cells (data not shown). In order to assess the effect of luteolin on IGFII secretion of HT-29 cells, cells were treated with 20 $60 \mu \mathrm{mol} / \mathrm{L}$ of luteolin for $24 \mathrm{~h}$ and conditioned media were assayed via immunoblot analysis. Luteolin reduced the secretion of pro- and mature-IGF-II in a dosedependent manner (Figure 1).

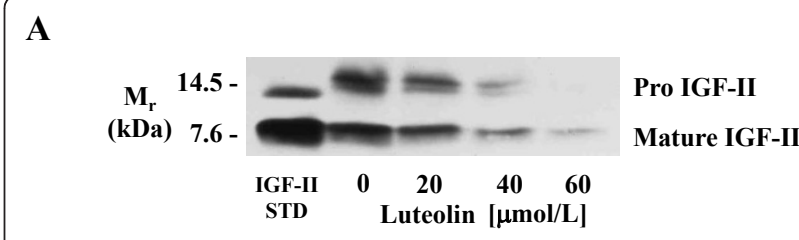

B
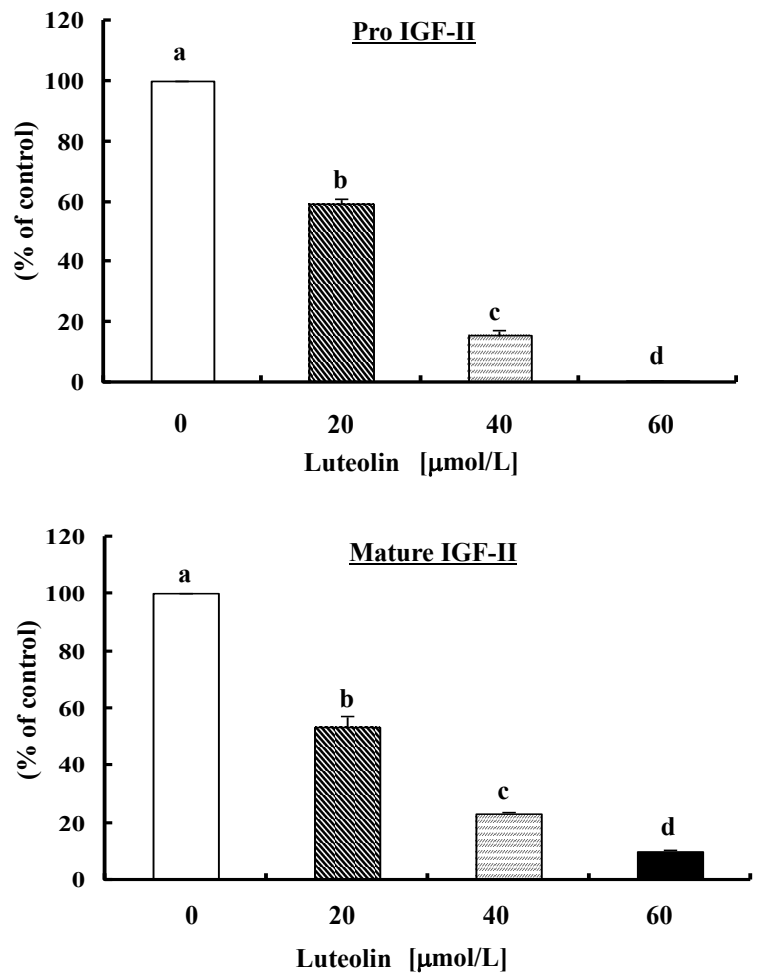

Figure 1 Luteolin reduces IGF-II secretion dose-dependently in HT-29 human colon cancer cells. (A) HT-29 cells were plated at a density of $2 \times 10^{6}$ cells/100 mm dish in DMEM/F12 supplemented with $10 \%$ FBS. After $24 \mathrm{~h}$, cells were serum-starved with serum-free DMEM/F12 supplemented with $5 \mathrm{mg} / \mathrm{L}$ of transferrin and $5 \mathrm{\mu g} / \mathrm{L}$ of selenium for $24 \mathrm{~h}$. Cells were treated with various concentrations ( 0 - $60 \mu \mathrm{mol} / \mathrm{L}$ ) of luteolin. $24 \mathrm{~h}$ after luteolin treatment, conditioned media were collected and concentrated for immunoblot analysis with an anti-IGF-II antibody. The volumes of media loaded onto the gels were adjusted for equivalent cell numbers. Photographs of the chemiluminescent detection of the blot, which were representative of three independent experiments, are shown. (B) The relative abundance of each band was quantified via densitometric scanning of the exposed films, and the control levels were set at 100\%. Each bar represents the mean \pm SEM $(n=3)$. Means without a common letter differ, $P<0.05$.

\section{Luteolin abrogates the growth stimulatory effects of} exogenous IGF-I on HT-29 cells

In order to determine whether luteolin inhibits the growth-stimulatory effects of exogenous IGF-I, cells were treated with 0 or $60 \mu \mathrm{mol} / \mathrm{L}$ of luteolin in the absence or presence of $10 \mathrm{nmol} / \mathrm{L}$ IGF-I for 24,48 , or 
72 h. IGF-I increased but luteolin significantly reduced the numbers of viable cells. The treatment of cells with IGF-I did not alleviate the growth-inhibitory effects of luteolin (Figure 2A). To explore the effect of luteolin on DNA synthesis in HT-29 cells, an $\left[{ }^{3} \mathrm{H}\right]$ thymidine incorporation assay was conducted. DNA synthesis was induced by IGF-I treatment, and luteolin significantly inhibited the stimulatory effect of IGF-I (Figure 2B).

Luteolin reduces the levels of the IGF-IR precursor protein and IGF-IR transcripts in HT-29 cells

Because luteolin reduced IGF-II secretion but exogenous IGF-I did not abrogate the growth-inhibitory effect of

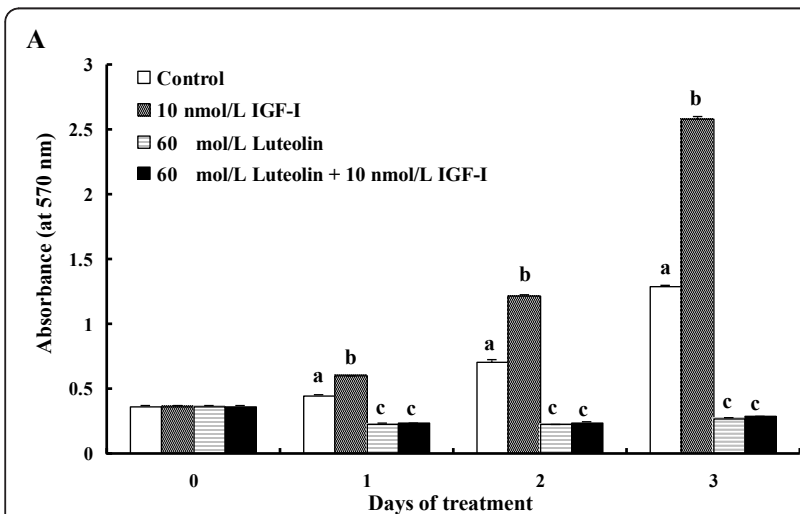

B

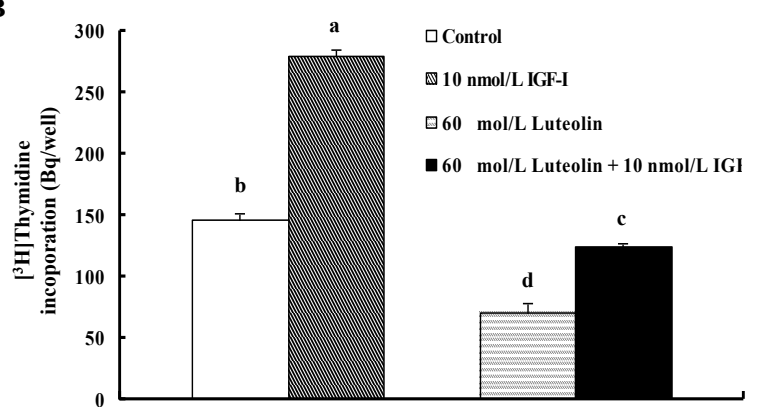

Figure 2 Luteolin abrogates the growth-stimulatory effects of exogenous IGF-I in HT-29 cells. (A) HT-29 cells were plated in 24well plates at a density of $5 \times 10^{4}$ cells/well. One day later, the cells were serum-starved for $24 \mathrm{~h}$ with serum-free DMEM/F12 supplemented with $5 \mathrm{mg} / \mathrm{L}$ transferrin, $0.1 \mathrm{~g} / \mathrm{L} \mathrm{BSA}$, and $5 \mu \mathrm{g} / \mathrm{L}$ selenium for $24 \mathrm{~h}$. After serum-starvation, the cells were incubated in serum-free medium containing 0 or $60 \mu \mathrm{mol} / \mathrm{L}$ of luteolin with or without $10 \mathrm{nmol} / \mathrm{L}$ of IGF-I for 24, 48, and $72 \mathrm{~h}$. Viable cell numbers were estimated via an MTT assay. (B) Cells were plated in 96-well plates at a density of $6 \times 10^{3}$ cells/well. Cells were serum-starved and then treated with 0 or $60 \mu \mathrm{mol} / \mathrm{L}$ of luteolin with or without 10 $\mathrm{nmol} / \mathrm{L}$ of IGF-I for $2 \mathrm{~h}$. $\left[^{3} \mathrm{H}\right]$ Thymidine was then added, and the incubation was continued for an additional $1 \mathrm{~h}$ in order to measure its incorporation into DNA. Each bar represents the mean \pm SEM ( $n$ =6). Means without a common letter differ, $P<0.05$. luteolin, we attempted to determine whether luteolin inhibits the IGF-I signaling pathway. Western blot analysis revealed that the levels of the IGF-IR precursor protein were reduced $2 \mathrm{~h}$ after the addition of luteolin, whereas the levels of the IGF-IR $\beta$-subunit were unaltered (Figure 3A). Additionally, IGF-IR transcript levels were reduced dose-dependently in cells treated with luteolin for $2 \mathrm{~h}$ (Figure 3B). Furthermore, the levels of IGF-IR mRNA were reduced further at $24 \mathrm{~h}$ of luteolin treatment as compared to those at $2 \mathrm{~h}$ (Figure $3 \mathrm{C}$ ).

\section{Luteolin inhibits IGF-I-induced activation of IGF-IR, Akt, and ERK1/2 in HT-29 cells}

In order to determine whether luteolin down-regulates IGF-I-induced tyrosine phosphorylation of the IGF-IR, cells were treated for $2 \mathrm{~h}$ with 0 or $60 \mu \mathrm{mol} / \mathrm{L}$ of luteolin, and IGF-IR was stimulated with $10 \mathrm{nmol} / \mathrm{L}$ IGF-I for 0,1 , or 30 minutes. Total cell lysates were prepared and immunoprecipitated using an IGF-IR $\beta$ antibody. The immune complexes were used for Western blot analysis with an anti-P-tyrosine antibody (PY20). IGF-I induced tyrosine phosphorylation of IGF-IR at $1 \mathrm{~min}$; tyrosine phosphorylation levels were slightly reduced at $30 \mathrm{~min}$. Luteolin significantly inhibited the phosphorylation of IGF-IR $\beta$ at $1 \mathrm{~min}$ after IGF-I treatment. At 30 min, the phosphorylation status of IGF-IR did not differ between the control and luteolin-treated cells.

To evaluate the association of the p85 subunit of PI3K with IGF-IR, we conducted immunoprecipitation of cell lysates with an IGF-IR $\beta$ antibody and subsequent immunoblotting with a p85 antibody. IGF-I stimulated the association of the p85 regulatory subunit of PI3K with IGF-IR within $1 \mathrm{~min}$, which was significantly inhibited by luteolin treatment (Figure $4 \mathrm{~A}$ ). The association of p85 with IGF-IR was reduced at $30 \mathrm{~min}$, and no difference was observed in the association of these two molecules between the control and luteolin-treated cells at this time period. Western blot analysis of total cell lysates revealed that IGF-I markedly increased P-IGF-IR levels and luteolin reduced those in both HT-29 and Caco-2 cells (Figure 4B). For the determination of PI3K activity, the immune complex was incubated with $\left[{ }^{32} \mathrm{P}\right]$ ATP and phosphatidylinositol. Luteolin reduced both basal and IGF-I-induced PI3K activity in HT-29 cells at 1 min of IGF-I treatment. However, this difference disappeared at $30 \mathrm{~min}$ after IGF-I treatment (Figure 4C). In order to determine whether the luteolin-induced inhibition of PI3K is the result of direct interaction with this kinase, active PI3K was incubated with $20 \mu \mathrm{mol} / \mathrm{L}$ of luteolin in the kinase reaction. Luteolin inhibited PI3K activity in a cell-free system (Figure 4D). The activation of PI3K leads to the activation of Akt [7]. Akt phosphorylation was induced by IGF-I treatment at 1 min without any changes in total Akt expression; 


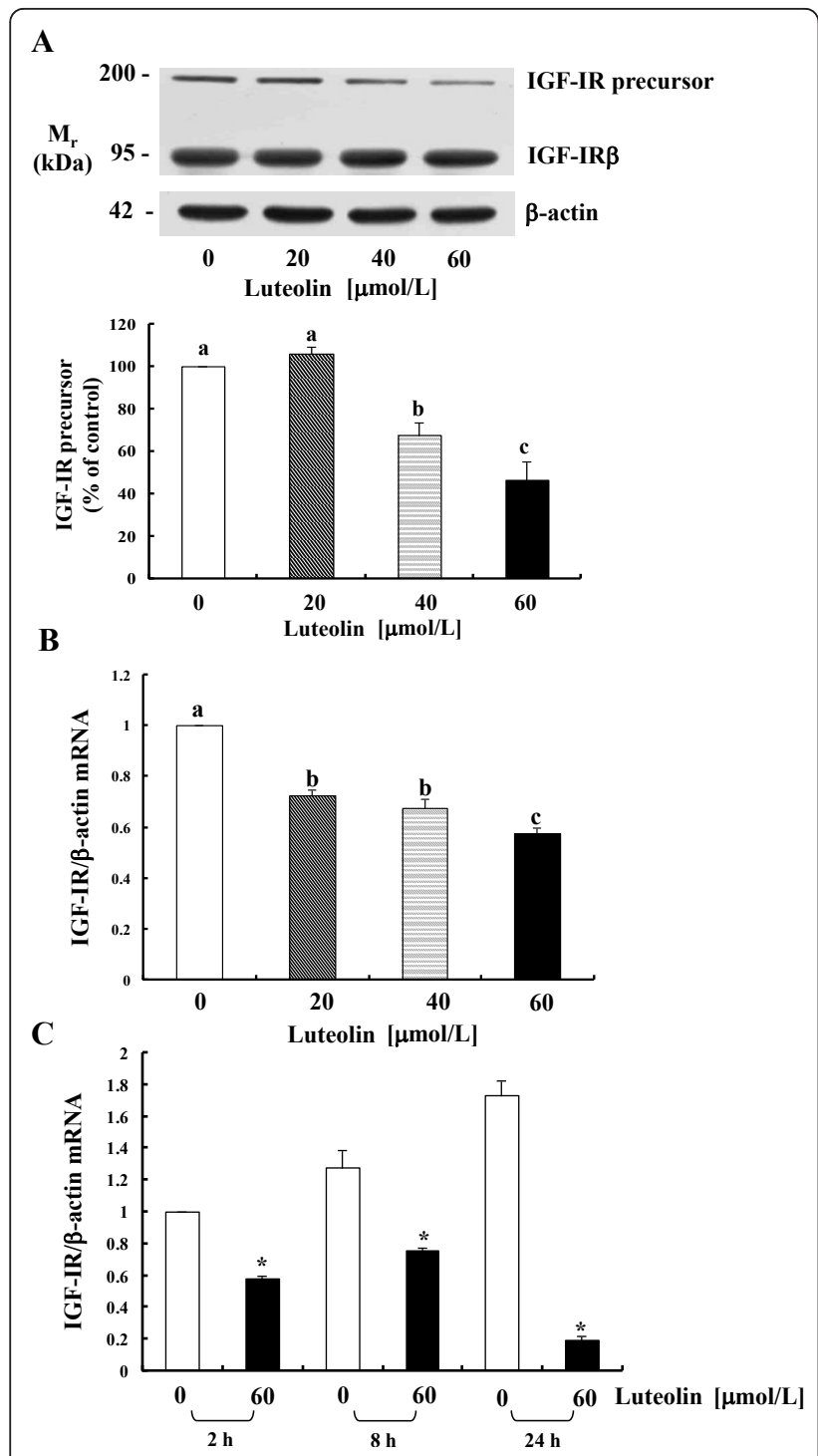

Figure 3 Luteolin reduces the levels of the IGF-IR protein and mRNA in HT-29 cells. (A) HT-29 cells were plated and treated with luteolin as described in Figure 1 for $2 \mathrm{~h}$. Total cell lysates were prepared and immunoblot analyses were conducted. Photographs of the chemiluminescent detection of the blots, which were representative of three independent experiments, were shown. The relative abundance of IGF-IR to their own $\beta$-actin was quantified via densitometric scanning of the exposed films, and the control levels were set at 100\%. (B)HT-29 cells were plated and treated with luteolin as described in Figure 1 for $2 \mathrm{~h}$. (C)HT-29 cells were treated with 0 or $60 \mu \mathrm{mol} / \mathrm{L}$ of luteolin for 2, 8, and $24 \mathrm{~h}$. (B, C) Total RNA was isolated and real-time PCR was conducted. Each bar represents mean \pm SEM $(n=3)$. (A, B) Means without a common letter differ, $P<0.05$. (C) *Different from $0 \mu \mathrm{mol} / \mathrm{L}$ of luteolin at each treatment time, $P<0.05$.

luteolin significantly reduced the level of Akt activation (Figure 5).

IGF-I stimulated ERK1/2 activation in HT-29 cells was detected at $30 \mathrm{~min}$ of IGF-I treatment, and luteolin inhibited the phosphorylation of ERK1/2 in the absence or presence of IGF-I treatment (Figure 6). Because ERK1/2 activation was reported to lead to the activation of the protein phosphatase CDC25c during the G2/M transition of cell cycle progression [26], we subsequently attempted to determine whether luteolin treatment results in a reduction in the phosphorylation of CDC25c. The levels of P-CDC25c were increased at 30 min after IGF-I addition and significantly reduced in cells treated with luteolin, regardless of whether or not the HT-29 cells were treated with IGF-I (Figure 6C).

\section{Discussion}

The IGF system (IGF-I, IGF-II, IGF-binding protein, and IGF-IR) performs an important role in the growth of various cancer cells, including colon cancer cells $[8,27]$. We have reported previously that luteolin inhibited the proliferation of HT-29 human colon cancer cells by inducing cell cycle arrest and apoptosis [21]. The results of a previous study revealed that luteolin reduced the expression of cyclin D1 and cyclin B1 and inhibited the activities of CDKs, thereby suppressing HT-29 cell cycle progression. Additionally, luteolin induced the activation of caspases and reduced the levels of proteins involved in the suppression of apoptosis, including Bcl-xL and Mdm-2 [21]. Thus, in the present study, we explored the upstream signals that are important for the regulation of cell cycle progression and apoptosis in HT-29 cells. Our previous data demonstrated that HT-29 cells synthesized and secreted IGF-II and expressed IGF-IR, and that IGF-II stimulated HT-29 cell growth via an autocrine mechanism [10,28]. Kim et al. also reported that the reduction of IGF-II secretion in Caco-2 colon cancer cells inhibited cell growth [11]. Using PC-3 and DU145 human prostate cancer cells, Fang et al. [29] have demonstrated that luteolin inhibits the IGF-I-induced activation of IGF-IR and AKT as well as the downstream targets of AKT, p70S6K1, GSK-3ß, and FKHR/FKHRL1. In the present study, we demonstrate that, in HT-29 human colon carcinoma cells, luteolin 1) reduces IGF-II secretion; 2) inhibits the growth-stimulatory effects of IGF-I; 3) reduces the levels of IGF-IR transcripts and the IGF-IR precursor protein; 4) reduces the IGF-I-induced tyrosine phosphorylation of IGF-IR $\beta$ and the association of $\mathrm{p} 85$ with IGF-IR $\beta$; 5) inhibits IGF-I-induced PI3K activity 6) inhibits IGF-I-induced Akt activation; and 7) inhibits the IGF-I-induced phosphorylation of ERK1/2 and $\mathrm{CDC} 25 \mathrm{c}$. These results indicate that the reduction in IGF-II secretion and changes in IGF-IR signaling by luteolin may be important factors underlying the growth-inhibitory effects of HT-29 cells. Additionally, we have demonstrated that luteolin directly inhibits the activity of PI3K in a cell-free system. 

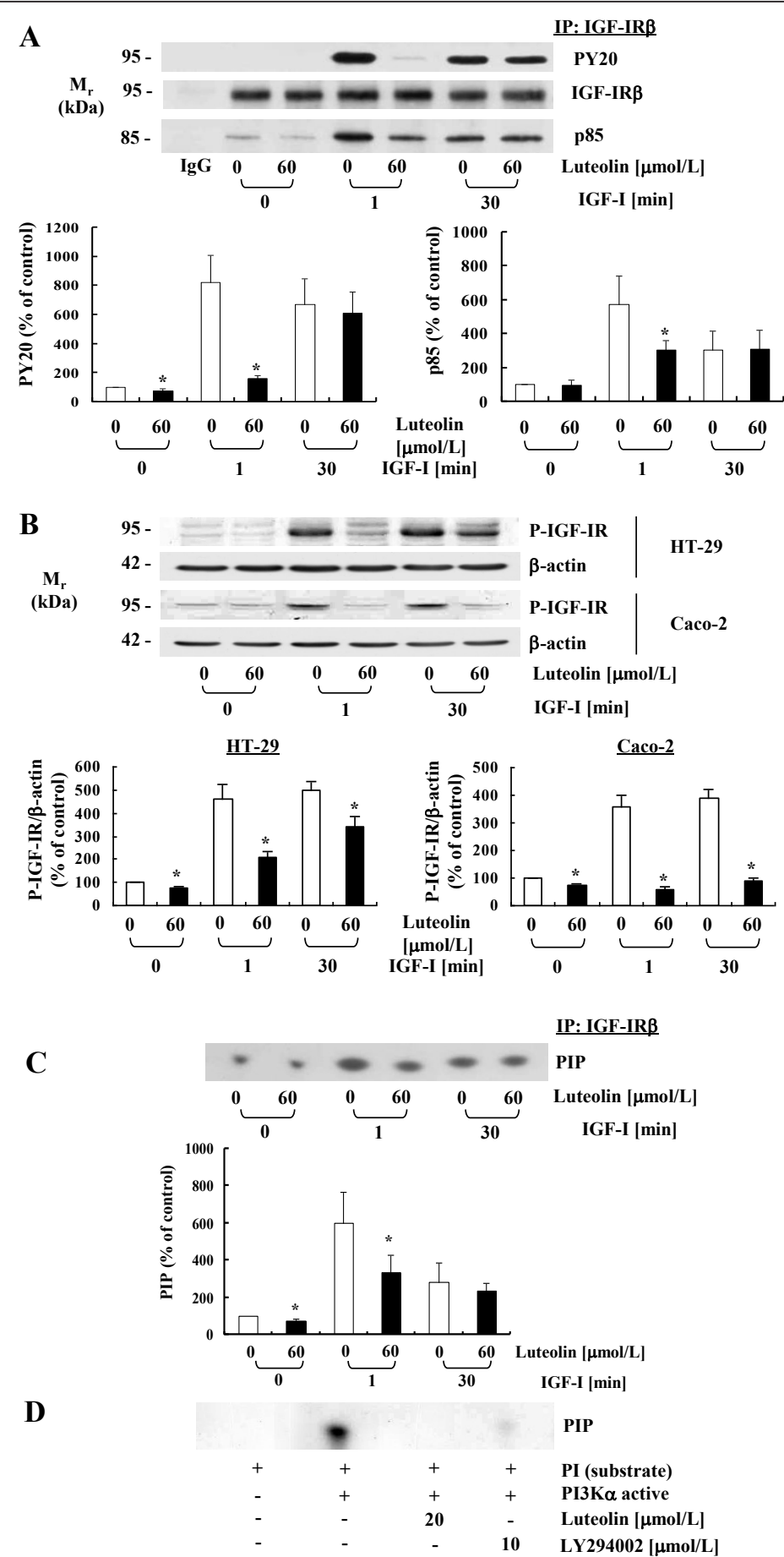

Figure 4 Effects of luteolin on IGF-I-induced tyrosine phosphorylation of IGF-IR, the association of p85 with IGF-IR, and PI3K activity in human colon cancer cells. Cells were plated and cultured as described in Figure 1. (A) HT-29 cells were treated for $2 \mathrm{~h}$ with 0 or $60 \mu \mathrm{mol} / \mathrm{L}$ of luteolin and lysed with or without stimulation of $10 \mathrm{nmol} / \mathrm{L}$ IGF-I for 0, 1, or 30 minutes. Total cell lysates were incubated with anti-IGF-IRB antibody and the immune complexes were precipitated with protein A-Sepharose. The immunoprecipitated proteins were analyzed via Western blotting with antibodies raised against phosphotyrosine (PY20), IGF-IRß, or p85. (B) HT-29 and Caco-2 cells were plated and treated as described above. Total cell lysates were analyzed via Western blotting with an antibody raised against P-IGF-IR. Photographs of the chemiluminescent detection of the blots, which were representative of three independent experiments, were shown. (C) The immune complexes obtained from HT-29 cells were incubated with phosphatidylinositol and [ $\gamma^{-32}$ P]ATP. (D) Active PI3K and luteolin were incubated with phosphatidylinositol and $\left[\gamma^{-32}\right.$ P]ATP as described in the Materials and Methods section. Phosphatidylinositol 3-phosphate (PIP) generated by immunoprecipitated PI3K (C) or active PI3Ka (D) was separated via thin-layer chromatography (TLC). An autoradiograph of the TLC plate, which was representative of three independent experiments, is shown. (A, B, C) The relative abundance of each blot was quantified via densitometric scanning of the exposed films and the control levels $(0 \mu \mathrm{mol} / \mathrm{L}$ luteolin, without IGF-I stimulation) were set at $100 \%$. Each bar represents the mean \pm SEM $(n=3)$. *Different from $0 \mu \mathrm{mol} / \mathrm{L}$ of luteolin at a stimulation time, $P<0.05$. 


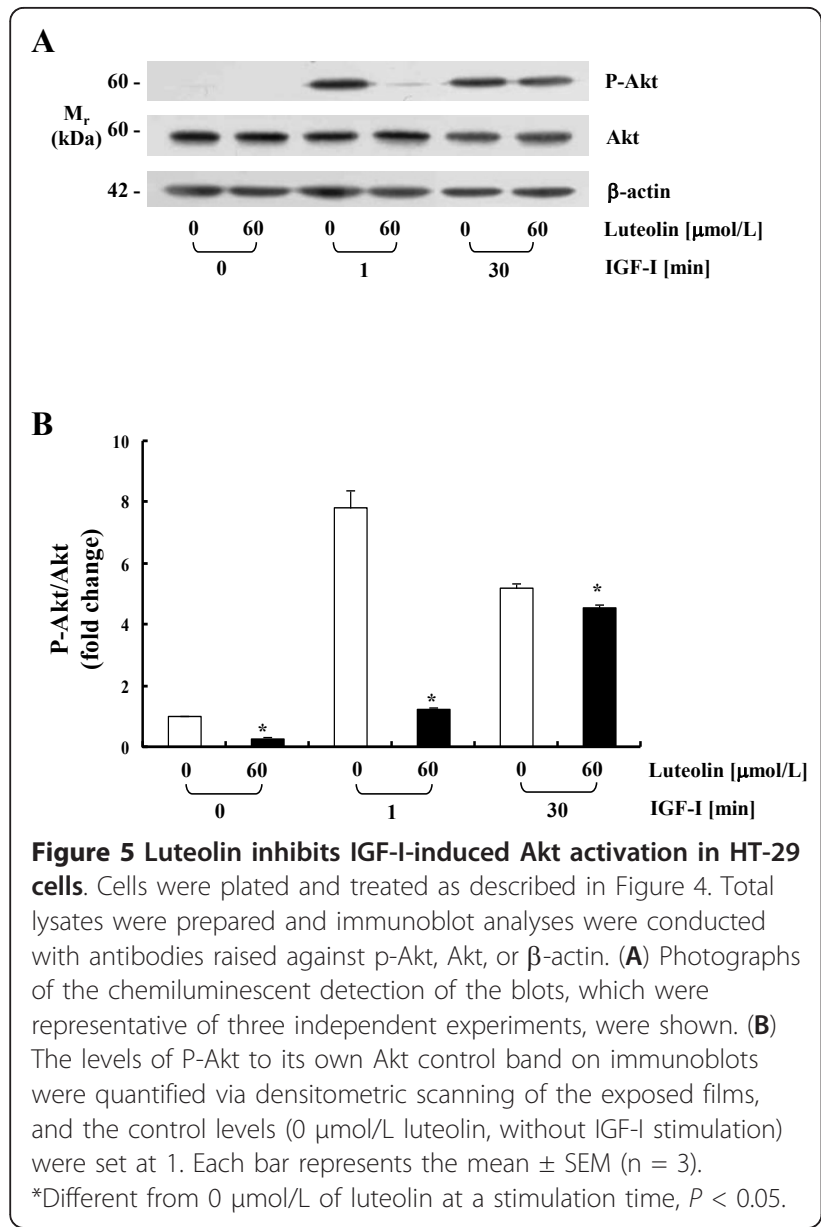

When HT-29 cells were treated with exogenous IGF-I, IGF-I did not abrogate the growth-inhibitory effects of luteolin (Figure 2), although luteolin reduced IGF-II secretion (Figure 1). These results indicated that luteolin inhibits IGF-IR signaling in HT-29 cells. IGF-IR consists of two extracellular $\alpha$-subunits and two transmembrane $\beta$-subunits, and IGF-I and IGF-II bind to the $\alpha$-subunits of IGF-IR, thus resulting in the activation of the intrinsic tyrosine kinase in the intracellular domain of the $\beta$ subunits [28]. In this study, luteolin reduced the levels of the IGF-IR precursor but did not reduce the levels of IGF-IR $\beta$-subunits; this suggests that the levels of IGFIR $\alpha$-subunits may have been reduced by luteolin treatment. The finding that IGF-IR mRNA levels were continuously decreased during $24 \mathrm{~h}$ of luteolin treatment (Figure 3C) indicates that the expression of IGF-IR protein is regulated by luteolin, at least in part, at an RNA level. The effects of luteolin on IGF-IR mRNA and protein stability will require further study in the future.

Fang et al. demonstrated that prostate cancer cells in which the IGF-IR gene is knocked down grew at a slower rate relative to that in control cells, and the inhibition of cell growth by luteolin treatment was similar

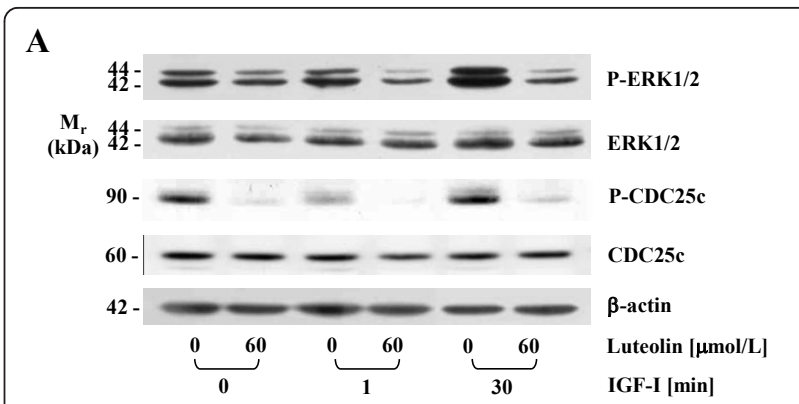

B
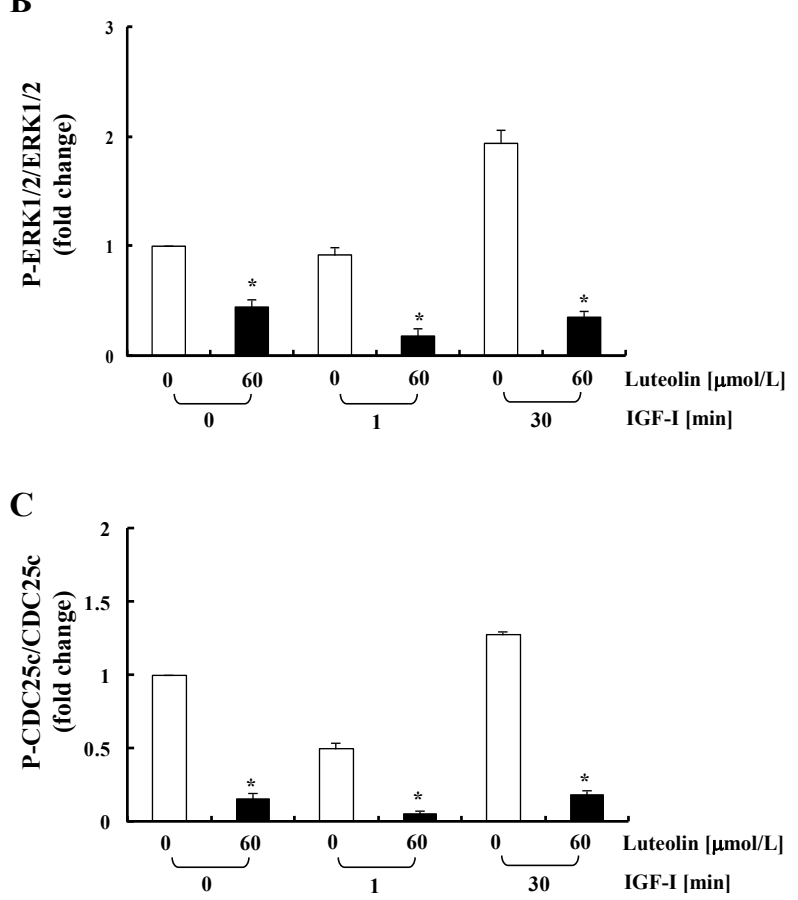

Figure 6 Luteolin inhibits IGF-I-induced ERK1/2 and CDC25C activation in HT-29 cells. Cells were plated and treated as described in Figure 4. Total lysates were prepared and immunoblot analyses were conducted with antibodies raised against P-ERK1/2, ERK1/2, P-CDC25C, CDC25C, or $\beta$-actin. (A) Photographs of the

chemiluminescent detection of the blots, which were representative of three independent experiments, were shown. (B, C) The levels of P-ERK $1 / 2$ to its own ERK $1 / 2$ control band (B) and those of P-CDC25C to its own $\mathrm{CDC} 25 \mathrm{C}$ control band $(\mathbf{C})$ on immunoblots were quantified via densitometric scanning of the exposed films, and the control levels ( $0 \mu \mathrm{mol} / \mathrm{L}$ luteolin, without IGF-I stimulation) were set at 1 . Each bar represents the mean $\pm \operatorname{SEM}(n=3)$. ${ }^{*}$ Different from 0 $\mu \mathrm{mol} / \mathrm{L}$ of luteolin at a stimulation time, $P<0.05$.

to that observed in IGF-IR-depleted cells [29]. In this study, we demonstrate that luteolin inhibits IGF-II secretion, and that IGF-I-stimulated HT-29 cell proliferation was inhibited by luteolin (Figure 2). These results suggest that the inhibition of the IGF/IGF-IR signaling pathway by luteolin might be one of the mechanisms for the suppression of proliferation and apoptosis in HT-29 cells. In 1994, Lahm et al. demonstrated that 
Alpha IR3, a neutralizing monoclonal antibody directed against human IGF-IR, inhibited proliferation in HT-29 cells [30]. It has also been demonstrated that the blockade of IGF-IR with IGF-IR monoclonal antibodies inhibited proliferation, arresting the cell cycle and inducing the apoptosis of HT-29 cells [31]. Additionally, an antihuman/mouse IGF-II-neutralizing antibody effectively inhibited the hepatic metastasis of HT-29 cells [32]. In vitro experiments have also demonstrated that IGF-IIneutralizing antibody treatment completely blocked IGF-IR phosphorylation in serum-starved HT-29 cells [33]. These results indicate that IGF-II is an autocrine growth factor of HT-29 cells and that the inhibition of IGF-II secretion and/or IGF-IR signaling inhibits HT-29 cell proliferation.

In our HT-29 cells, it is possible that the luteolininduced downregulation of the IGF-IR $\alpha$-subunit results in reduced phosphorylation of the $\beta$-subunit. It is also possible that luteolin directly interferes with the binding of IGF-I to IGF-IR, which would consequently inhibit the phosphorylation of the $\beta$-subunit. This reduced IGF-Iinduced tyrosine phosphorylation of IGF-IR $\beta$ by luteolin led to the reduced association of p85 with IGF-IR $\beta$ and the subsequent activation of PI3K/Akt and ERK1/2 (Figures 4, 5 and 6). Additionally, luteolin inhibited PI3K activity in a cell-free system (Figure 4D), thereby indicating that luteolin can also modulate the activity of this enzyme via direct interaction with this kinase. As the activation of Akt and ERK1/2 induces cell proliferation and inhibits apoptosis in various cancers [34,35], the PI3K/Akt and ERK1/2 pathways may be important targets in cancer therapies involving natural bioactive compounds [6,23,28,29,36-38]. Akt regulates the expression and activity of proteins involved in the regulation of apoptosis and cell cycle progression, including Bad, p21, cyclin D1, and Mdm-2 (Reviewed in [37]). Previously, we have demonstrated that luteolin downregulates the expression of Mdm-2 and cyclin D1 [21]. Fang et al. also reported that luteolin treatment induced a reduction in the levels of P-IGF-IR, P-Akt, and cyclin D1 in PC3 prostate cancer cells [29]. The results of previous studies and of the present study indicate that the inhibition of Akt activation by luteolin may result in the downregulation of Mdm-2 and cyclin D1, which may contribute to the induction of apoptosis and cell cycle arrest in colon and prostate cancer cells. Collectively, these results indicate that the downregulation of IGF-IR/PI3K/Akt by luteolin is one of the principal signaling pathways for the induction of cell cycle arrest and apoptosis in HT-29 cells.

ERK-MAP kinases also regulate cell cycle- and apoptosis-related proteins. ERK1/2 activation leads to the phosphorylation of the protein phosphatase CDC25c during the $\mathrm{G} 2 / \mathrm{M}$ transition of cell cycle progression [26]. Phosphorylated CDC25c dephosphorylates CDC2, which results in the activation of the CDC2/cyclin B1 complex. Luteolin has been reported to reduce the levels of the $\mathrm{CDC} 25 \mathrm{c}, \mathrm{CDC} 2$, and cyclin $\mathrm{B} 1$ proteins and induces $\mathrm{G} 2 / \mathrm{M}$ phase arrest in human gastric cancer cell lines [39]. In our previous study, luteolin reduced cyclin B1 levels, markedly inhibited CDC2 activity, and promoted G2/M phase arrest in HT-29 cells [21]. In the present study, we determined that luteolin reduced the levels of P-CDC25c in HT-29 cells (Figure 6C). Together, these results indicate that the attenuated ERK1/2 activation contributed to the reduction of PCDC25c levels in luteolin-treated cells. The reduction in CDC25c activation may have contributed to the induction of G2/M arrest in HT-29 cells.

\section{Conclusions}

We demonstrated that luteolin reduced the secretion of pro- and mature-IGF-II and reduced the levels of the IGF-IR precursor protein in HT-29 cells, and subsequently reduced the activation of the Akt and ERK1/2 pathways. The inhibition of the IGF-IR signaling pathway may be one of the mechanisms by which luteolin inhibits Akt and ERK1/2 signaling in HT-29 cells, thereby inhibiting cell growth and inducing apoptosis (Figure 7). The present results help delineate the

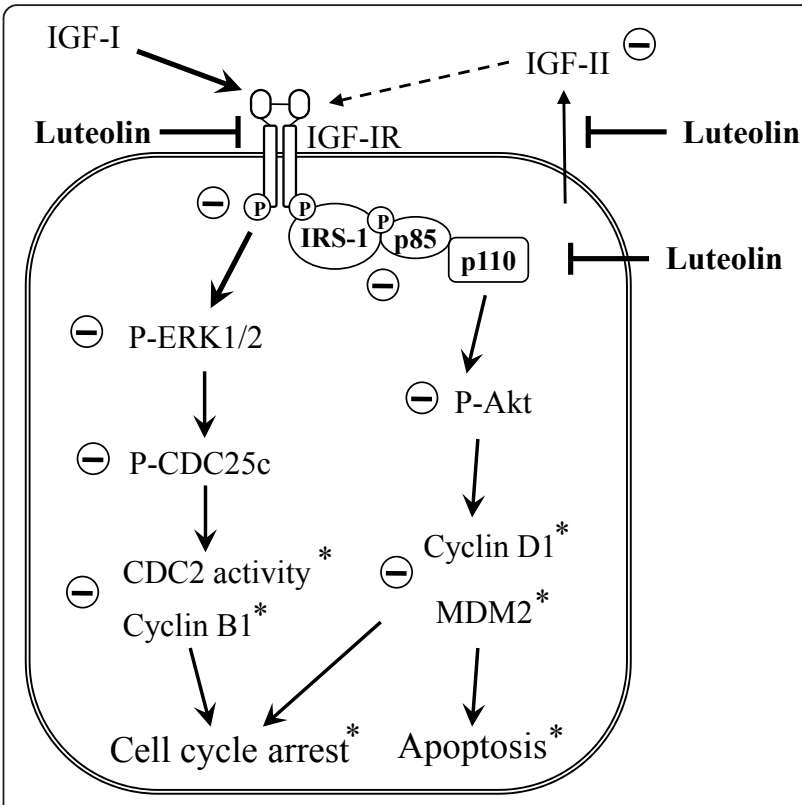

Figure 7 A tentative scheme for luteolin regulation of the IGFIR signaling pathway in HT-29 human colon cancer cells. Luteolin reduces the secretion of IGF-II and levels of IGF-IR mRNA and protein, which leads to a reduction in IGF-IR phosphorylation and a subsequent inhibition of PI3K/Akt and ERK1/2/CDC25C activation. Additionally, luteolin directly inhibits PI3K activity. These changes in IGF-I signaling contribute to luteolin-induced apoptosis and cell cycle arrest in HT-29 cells. *From our previously published results [21]. 
mechanisms of luteolin actions for future animal studies with colon cancer models. Such studies will determine whether luteolin can be developed into a chemopreventive agent for use against colon cancer.

\section{Abbreviations}

IGF-IR: insulin-like growth factor-1 receptor; IGF-II: insulin-like growth factor-II; ERK-1/2: extracellular signal-regulated kinase-1/2; PI3K: phophatidylinositol-3 kinase; PIP: phosphatidylinositol 3-phosphate; TLC: thin layer chromatography; CDK: cyclin-dependent kinase; CDC: cell division cycle.

\section{Acknowledgements}

This study was supported by the Regional Core Research Program/Medical \& Bio-Material Research Center, the Mid-career Researcher Program (20100006923), and the SRC program (Center for Food \& Nutritional Genomics: grant number 2010-0001886) of the National Research Foundation (NRF) of Korea, funded by the Ministry of Education, Science, and Technology.

\section{Author details}

'Department of Food Science and Nutrition, Hallym University, Chuncheon, 200-702, Korea. ${ }^{2}$ Medical \& Bio-Materials Research Center, Kangwon National University, Chuncheon, 200-701, Korea. ${ }^{3}$ Department of Food Science and Biotechnology, Kangwon National University, Chuncheon, 200-701, Korea. ${ }^{4}$ Functional Food Center, Korea Institute of Science and Technology, Gangneung Institute, Gangneung, 210-340, Korea. ${ }^{5}$ Department of Agricultural Biotechnology and Center for Agricultural Biomaterials, Seoul National University, Seoul, 151-921, Korea.

\section{Authors' contributions}

DYL, JK, KWL, and JHYP planned and designed this research; DYL and HJC performed the assays and analyzed the data; DYL wrote the first draft and JHYP, DYL, HJC, and CWN revised the paper. All authors read and approved the final manuscript.

\section{Competing interests}

The authors declare that they have no competing interests.

Received: 24 June 2011 Accepted: 23 January 2012

Published: 23 January 2012

\section{References}

1. Roghani M, Lassarre C, Zapf J, Povoa G, Binoux M: Two insulin-like growth factor (IGF)-binding proteins are responsible for the selective affinity for IGF-II of cerebrospinal fluid binding proteins. J Clin Endocrinol Metab 1991, 73(3):658-666.

2. Lock K, Pomerleau J, Causer L, Altmann DR, McKee M: The global burden of disease attributable to low consumption of fruit and vegetables: implications for the global strategy on diet. Bull World Health Organ 2005, 83(2):100-108.

3. Baserga R, Hongo A, Rubini M, Prisco M, Valentinis B: The IGF-I receptor in cell growth, transformation and apoptosis. Biochim Biophys Acta 1997, 1332(3):F105-126.

4. Dupont J, LeRoith D: Insulin and insulin-like growth factor I receptors: similarities and differences in signal transduction. Horm Res 2001, 55(Suppl 2):22-26.

5. Le Roith D, Bondy C, Yakar S, Liu JL, Butler A: The somatomedin hypothesis: 2001. Endocr Rev 2001, 22(1):53-74.

6. Alexia C, Lasfer M, Groyer A: Role of constitutively activated and insulinlike growth factor-stimulated ERK1/2 signaling in human hepatoma cell proliferation and apoptosis: evidence for heterogeneity of tumor cell lines. Ann N Y Acad Sci 2004, 1030:219-229.

7. Pollak MN, Schernhammer ES, Hankinson SE: Insulin-like growth factors and neoplasia. Nat Rev Cancer 2004, 4(7):505-518.

8. Frasca F, Pandini G, Sciacca L, Pezzino V, Squatrito S, Belfiore A, Vigneri R: The role of insulin receptors and IGF-I receptors in cancer and other diseases. Arch Physiol Biochem 2008, 114(1):23-37.

9. Zhang $L$, Zhou W, Velculescu VE, Kern SE, Hruban RH, Hamilton SR, Vogelstein B, Kinzler KW: Gene Expression Profiles in Normal and Cancer Cells. Science 1997, 276(5316):1268-1272.
10. Oh YS, Kim EJ, Schaffer BS, Kang YH, Binderup L, MacDonald RG, Park JH: Synthetic low-calcaemic vitamin $D(3)$ analogues inhibit secretion of insulin-like growth factor II and stimulate production of insulin-like growth factor-binding protein-6 in conjunction with growth suppression of HT-29 colon cancer cells. Mol Cell Endocrinol 2001, 183(1-2):141-149.

11. Kim EJ, Holthuizen PE, Park HS, Ha YL, Jung KC, Park JH: Trans-10, cis-12conjugated linoleic acid inhibits Caco-2 colon cancer cell growth. Am J Physiol Gastrointest Liver Physiol 2002, 283(2):G357-367.

12. Kim HK, Cheon BS, Kim YH, Kim SY, Kim HP: Effects of naturally occurring flavonoids on nitric oxide production in the macrophage cell line RAW 264.7 and their structure-activity relationships. Biochem Pharmacol 1999, 58(5):759-765.

13. Chen CC, Chow MP, Huang WC, Lin YC, Chang YJ: Flavonoids inhibit tumor necrosis factor-alpha-induced up-regulation of intercellular adhesion molecule-1 (ICAM-1) in respiratory epithelial cells through activator protein-1 and nuclear factor-kappaB: structure-activity relationships. Mol Pharmacol 2004, 66(3):683-693.

14. Hu C, Kitts DD: Luteolin and luteolin-7-O-glucoside from dandelion flower suppress iNOS and COX-2 in RAW264.7 cells. Mol Cell Biochem 2004, 265(1-2):107-113.

15. Kumazawa $Y$, Kawaguchi $K$, Takimoto H: Immunomodulating effects of flavonoids on acute and chronic inflammatory responses caused by tumor necrosis factor alpha. Curr Pharm Des 2006, 12(32):4271-4279.

16. Chang J, Hsu Y, Kuo P, Kuo Y, Chiang L, Lin C: Increase of Bax/Bcl-XL ratio and arrest of cell cycle by luteolin in immortalized human hepatoma cell line. Life Sci 2005, 76(16):1883-1893.

17. Leung $\mathrm{HW}, \mathrm{Wu} \mathrm{CH}$, Lin $\mathrm{CH}$, Lee HZ: Luteolin induced DNA damage leading to human lung squamous carcinoma $\mathrm{CH} 27$ cell apoptosis. Eur $J$ Pharmacol 2005, 508(1-3):77-83.

18. Cheng AC, Huang TC, Lai CS, Pan MH: Induction of apoptosis by luteolin through cleavage of $\mathrm{Bcl}-2$ family in human leukemia HL-60 cells. Eur J Pharmacol 2005, 509(1):1-10.

19. Horinaka M, Yoshida T, Shiraishi T, Nakata S, Wakada M, Nakanishi R, Nishino H, Matsui H, Sakai T: Luteolin induces apoptosis via death receptor 5 upregulation in human malignant tumor cells. Oncogene 2005, 24(48):7180-7189.

20. Lee HJ, Wang CJ, Kuo HC, Chou FP, Jean LF, Tseng TH: Induction apoptosis of luteolin in human hepatoma HepG2 cells involving mitochondria translocation of Bax/Bak and activation of JNK. Toxicol Appl Pharmacol 2005, 203(2):124-131

21. Lim do $Y$, Jeong $Y$, Tyner AL, Park JH: Induction of cell cycle arrest and apoptosis in HT-29 human colon cancer cells by the dietary compound luteolin. Am J Physiol Gastrointest Liver Physiol 2007, 292(1):G66-75.

22. Kim EJ, Kang YH, Schaffer BS, Bach LA, MacDonald RG, Park JH: Inhibition of Caco-2 cell proliferation by all-trans retinoic acid: role of insulin-like growth factor binding protein-6. J Cell Physiol 2002, 190(1):92-100.

23. Cho HJ, Kim WK, Kim EJ, Jung KC, Park S, Lee HS, Tyner AL, Park JH: Conjugated linoleic acid inhibits cell proliferation and ErbB3 signaling in HT-29 human colon cell line. Am J Physiol Gastrointest Liver Physiol 2003, 284(6):G996-1005.

24. Cho HJ, Seon MR, Lee YM, Kim J, Kim JK, Kim SG, Park JH: 3,3'Diindolylmethane suppresses the inflammatory response to lipopolysaccharide in murine macrophages. J Nutr 2008, 138(1):17-23.

25. Gu C, Park S: The EphA8 receptor regulates integrin activity through p110gamma phosphatidylinositol-3 kinase in a tyrosine kinase activityindependent manner. Mol Cell Biol 2001, 21(14):4579-4597.

26. Wang R, He G, Nelman-Gonzalez M, Ashorn CL, Gallick GE, Stukenberg PT, Kirschner MW, Kuang J: Regulation of Cdc25C by ERK-MAP kinases during the G2/M transition. Cell 2007, 128(6):1119-1132.

27. Jung Jl, Cho HJ, Kim J, Kwon DY, Park JH: trans-10, cis-12 conjugated linoleic acid inhibits insulin-like growth factor-I receptor signaling in TSU-Pr1 human bladder cancer cells. J Med Food 13(1):13-19.

28. Kim EJ, Kang IJ, Cho HJ, Kim WK, Ha YL, Park JH: Conjugated linoleic acid downregulates insulin-like growth factor-I receptor levels in HT-29 human colon cancer cells. J Nutr 2003, 133(8):2675-2681.

29. Fang J, Zhou Q, Shi XL, Jiang BH: Luteolin inhibits insulin-like growth factor 1 receptor signaling in prostate cancer cells. Carcinogenesis 2007, 28(3):713-723.

30. Lahm H, Amstad P, Wyniger J, Yilmaz A, Fischer JR, Schreyer M, Givel JC: Blockade of the insulin-like growth factor-I receptor inhibits growth of 
human colorectal cancer cells: evidence of a functional IGF-II-mediated autocrine loop. Int J Cancer 1994, 58:452-459.

31. Zhang Y: Growth inhibition of insulin-like growth factor I receptor monoclonal antibody to human colorectal cancer cells. Cancer Invest 2008, 26(3):230-236.

32. Miyamoto S, Nakamura M, Shitara K, Nakamura K, Ohki Y, Ishii G, Goya M, Kodama K, Sangai T, Maeda H, Shi-Chuang Z, Chiba T, Ochiai A: Blockade of paracrine supply of insulin-like growth factors using neutralizing antibodies suppresses the liver metastasis of human colorectal cancers. Clin Cancer Res 2005, 11(9):3494-3502.

33. Miyamoto $S$, Nakamura M, Yano K, Ishii G, Hasebe T, Endoh $Y$, Sangai T, Maeda H, Shi-Chuang Z, Chiba T, Ochiai A: Matrix metalloproteinase-7 triggers the matricrine action of insulin-like growth factor-II via proteinase activity on insulin-like growth factor binding protein 2 in the extracellular matrix. Cancer Sci 2007, 98(5):685-691.

34. Mebratu Y, Tesfaigzi Y: How ERK1/2 activation controls cell proliferation and cell death: Is subcellular localization the answer? Cell Cycle 2009, 8(8):1168-1175.

35. Carnero A: The PKB/AKT pathway in cancer. Curr Pharm Des 2010, 16(1):34-44.

36. Cho HJ, Kim WK, Jung JI, Kim EJ, Lim SS, Kwon DY, Park JH: Trans-10,cis-12, not cis-9,trans-11, conjugated linoleic acid decreases ErbB3 expression in HT-29 human colon cancer cells. World J Gastroenterol 2005, 11(33):5142-5150.

37. Schmitz KJ, Lang H, Wohlschlaeger J, Sotiropoulos GC, Reis H, Schmid KW, Baba HA: AKT and ERK1/2 signaling in intrahepatic cholangiocarcinoma. World J Gastroenterol 2007, 13(48):6470-6477.

38. Byun S, Lee KW, Jung SK, Lee EJ, Hwang MK, Lim SH, Bode AM, Lee HJ, Dong Z: Luteolin inhibits protein kinase C(epsilon) and c-Src activities and UVB-induced skin cancer. Cancer Res 70(6):2415-2423.

39. Wu B, Zhang Q, Shen W, Zhu J: Anti-proliferative and chemosensitizing effects of luteolin on human gastric cancer AGS cell line. Mol Cell Biochem 2008, 313(1-2):125-132.

\section{Pre-publication history}

The pre-publication history for this paper can be accessed here: http://www.biomedcentral.com/1471-230X/12/9/prepub

doi:10.1186/1471-230X-12-9

Cite this article as: Lim et al:: Luteolin decreases IGF-II production and downregulates insulin-like growth factor-I receptor signaling in HT-29 human colon cancer cells. BMC Gastroenterology 2012 12:9.

\section{Submit your next manuscript to BioMed Central and take full advantage of:}

- Convenient online submission

- Thorough peer review

- No space constraints or color figure charges

- Immediate publication on acceptance

- Inclusion in PubMed, CAS, Scopus and Google Scholar

- Research which is freely available for redistribution

Submit your manuscript at www.biomedcentral.com/submit
Biomed Central 